\title{
CAMPUR KODE DALAM KOMUNIKASI LISAN PASANGAN PERKAWINAN BEDA BANGSA JEPANG-INDONESIA (KAJIAN SOSIOLINGUISTIK)
}

\author{
Putu Dewi Merlyna Y.P,S.S,M.Hum ${ }^{1}$, Ida Ayu Made Darmayanti,S.Pd,M.Pd ${ }^{2}$ \\ ${ }^{1}$ Jurusan Pendidikan Bahasa Jepang, 2 Jurusan Pendidikan Bahasa dan Sastra Indonesia, \\ Universitas Pendidikan Ganesha, Singaraja, Indonesia
}

\begin{abstract}
Abstrak
Masyarakat Indonesia adalah masyarakat dwibahasawan yang mampu berkomunikasi dengan lebih dari satu bahasa. Hubungan sosial di daerah pariwisata mengakibatkan akulturasi budaya dan bahasa yang melahirkan hubungan personal antar individu. Hubungan personal seperti perkawinan beda bahasa antara warga Jepang dan warga Indonesia memunculkan campur kode dalam kegiatan komunikasinya. Penelitian ini bertujuan mengetahui jenis campur kode yang digunakan, jenis campur kode yang paling dominan dipakai, dan alasan terjadinya campur kode dalam berkomunikasi. Metode yang dipakai adalah metode observasi dan wawancara,kemudian dianalisis dengan metode deskriptif kualitatif. Hasil penelitian ini adalah ada tiga jenis campur kode yang muncul. Jenis campur kode yang paling dominan adalah campur kode keluar. Faktor yang mengakibatkan fenomena campur kode adalag faktor kesantaian, kebiasaan, dan karena kurangnya padanan kata yang dapat digunakan berkomunikasi dengan bahasa yang sama.
\end{abstract}

Kata kunci: campur kode, komunikasi

\begin{abstract}
Indonesia is a socially, culturally, as well as linguistically complex society. Regarding its linguistic aspect, Indonesian people are considered as bilingual since they can speak more than one language. The social interaction in a tourism object, cultural and linguistic acculturations may take place among individuals living in that place. Due to such phenomenon, the researcher investigated the use of oral linguistic code-mixing among a Japanese and Balinese marriage. This study aimed at finding out the code mixing types happening in the oral communications, the dominant code mixing types, and the reasons underlying such code mixing. The data were collected by using observation and interview instruments and analyzed by a qualitative descriptive method. The result of this research showed that in oral communicatios the three code-mixing types occurred in every utterance. The dominant code-mixing types mostly existed was outer code-mixing. The factors promoting the studied code mixing phenomenon above were the pleasure factor, habit, and the lack of synonyms which can be uttered in the same language.
\end{abstract}

Keywords : code-mixing, oral communication

\section{PENDAHULUAN}

Bahasa adalah sistem lambang bunyi yang arbitrer, yang digunakan oleh anggota masyarakat untuk bekerja sama, berinteraksi, dan mengidentifikasi diri (Depdikbud, 2005:88). Oleh karena, bahasa merupakan suatu sistem, maka bahasa tersebut mempunyai aturan-aturan yang saling bergantung dan mengandung unsur- unsur yang dianalisis secara terpisah. Dalam situasi pertuturan baik yang bersifat formal maupun yang bersifat informal, baik lisan maupun tulis sering ditemukan fenomena orang bertutur dengan menggunakan bahasa tertentu tiba-tiba mengganti bahasanya. Mengganti bahasa diartikan sebagai tindakan mengalihkan bahasa maupun mencampur antara bahasa 
satu dengan bahasa lainnya. Penggantian bahasa atau ragam bahasa bergantung pada keadaan atau keperluan bahasa itu (Nababan, 1986:31).

Seperti yang telah kita ketahui, masyarakat Indonesia merupakan masyarakat yang majemuk, baik secara sosial, budaya, maupun bahasa. Ditinjau dari pandangan linguistik, masyarakat yang bilingual (dwibahasawan) yaitu masyarakat yang menggunakan dua bahasa atau lebih dalam berkomunikasi (Keraf, 1993:7). Pendapat Keraf juga didukung oleh Suhardi (2009:42) yang menyatakan bahwa bilingualisme pada umumnya dipakai untuk menunjukkan pemakaian atau penguasaan dua bahasa atau lebih oleh seseorang.

Berdasarkan aspek linguistik ini, masyarakat Bali merupakan masyarakat yang bilingual (dwibahasa). Selain sebagai masyarakat bilingual, di beberapa daerah di Bali khususnya daerah pariwisata, masyarakatnya cenderung multilingual. Selain menggunakan bahasa Bali dan Indonesia, mereka juga mampu menggunakan bahasa asing, misalnya bahasa Inggris, bahasa Jepang, dan bahasa lainnya. Salah satu daerah pariwisata yang masyarakatnya berinteraksi secara multilingual adalah kawasan pariwisata Sanur yang berada di Kota Denpasar. Dengan datangnya wisatawan asing dari mancanegara, memungkinkan masyarakat lokal untuk berinteraksi dengan menggunakan bahasa asing. Interaksiinteraksi yang terjadi antara orang lokal dengan orang asing terjadi baik dari segi ekonomi-bisnis, maupun sosial-budaya. Dari hubungan sosial yang terjadi, daerah pariwisata memungkinkan adanya hubungan antar bangsa yang bersifat personal antara satu individu dengan individu lainnya. Ini memungkinkan terjadinya perkawinan beda bangsa, yaitu perkawinan antara orang lokal (WNI) dengan orang asing (WNA).

Dalam perkawinan beda bangsa tersebut, anak-anak hasil perkawinan kedua individu tersebut akan tumbuh dengan bahasa dan budaya yang berbeda. Bahasa yang digunakan dalam pasangan perkawinan beda bangsa khususnya bahasa yang digunakan oleh anak-anak dipengaruhi oleh bahasa orang tua mereka. Dalam percakapan menggunakan bahasa Bali, bahasa Indonesia, maupun bahasa asing, beberapa kata atau frasa dapat saja diujarkan secara bercampur yang menyebabkan terjadinya percampuran kode bahasa yang biasa disebut dengan code mixing.

Adapun tujuan penelitian ini adalah untuk mengetahui jenis campur kode yang terjadi dalam komunikasi, jenis campur kode yang paling dominan terjadi, serta alasan penggunaan campur kode oleh pasangan perkawinan beda bangsa Jepang-Indonesia di daerah pariwisata Sanur.

\section{METODE}

Rancangan penelitian ini menggunakan metode deskriptif kualitatif. Lokasi penelitian adalah rumah seorang warga Jepang yang melakukan perkawinan beda bangsa dengan warga Indonesia. Rumah subyek penelitian berada di Jalan Danau Tamblingan, Sanur.

Metode pengumpulan data adalah metode observasi dan wawancara yang diolah secara deskriptif kualitatif. Pada proses observasi untuk memperkuat data peneliti menggunakan teknik rekam dan catat, hal ini dimaksudkan untuk meminimalkan data ujaran yang terlewati, sehingga data yang di dapat lebih akurat. Metode observasi digunakan untuk menemukan data berupa ujaran-ujaran yang mengandung campur kode. Sedangkan metode wawancara digunakan untuk mendapat jawaban atas rumusan masalah ke dua dan ketiga yakni yang berkenaan dengan jenis campur kode yang paling dominan serta faktor yang mengakibatkan munculnya campur kode tersebut.

\section{HASIL DAN PEMBAHASAN}

Berdasarkan hasil analisis data yang diperoleh dari penggunaan campur 
kode dalam komunikasi lisan pasangan perkawinan beda bangsa di daerah pariwisata Sanur, terjadi 212 dialog dalam kegiatan observasi yang dilakukan, namun beberapa dari dialog tersebut harus direduksi karena tidak relevan dengan tujuan penelitian. Adapun data yang tereduksi sebanyak 58 dialog. Dialog-dialog tersebut harus direduksi karena tidak relevan dengan ruang lingkup penelitian. Dialog-dialog tersebut dikatakan tidak relevan karena subjek pada data di atas bukanlah orang dari pasangan perkawinan beda bangsa yang peneliti teliti melainkan orang-orang yang terlibat pembicaraan dengan subjek penelitian yang secara tidak langsung juga menggunakan campur kode dalam proses berkomunikasi. Berikut disajikan hasil dari analisis data penelitian.

\section{Jenis Campur Kode}

Jenis campur kode yang muncul pada kegiatan komunikasi dari pasangan perkawinan beda bangsa Jepang-Indonesia pada penelitian ini ada tiga jenis campur kode antara lain campur kode ke luar (outer code mixing), campur kode ke dalam (inner code mixing), serta campur kode campuran (hybrid code mixing). Masing-masing contoh dialog dari jenis campur kode tersebut, dapat dilihat berikut ini.

\section{a. Campur Kode ke Luar (outer code mixing)}

Dialog berikut menunjukkan adanya campur kode ke luar yang terjadi dalam kegiatan berkomunikasi S1 (Subjek 1) dengan P1 (Partisipan 1). Penggalan dialognya sebagai berikut.

$\begin{array}{ll}\text { Tape } 2 & \text { : Jumat 21 Juli } 2012 \\ \text { Dialog } 1 & \text { : Masalah Pergaulan } \\ \text { Setting } & \text { : Kamar Tamu }\end{array}$

$\mathbf{S} 1 \mathrm{I} \rightarrow \mathbf{J}$ dan $\mathbf{E} \leftarrow \mathbf{J} \quad$ : Kalo pikirpikir..ano...orang Indonesia punya best friend banyak bagus ya...

Subjek 1 menggunakan campur kode antara bahasa Indonesia dengan Jepang serta bahasa Inggris, yaitu "Kalo pikir-pikir"," orang Indonesia"," punya", "banyak", "bagus ya" dengan "ano". Disini subjek banyak mencampurkan bahasa pada dialognya, mulai dari kata "ano" yang memiliki makna sama sedikit berpikir, diucapkan dengan bahasa Jepang oleh subjek. Dalam penggalan dialog di atas, S1 juga mencampur bahasanya dengan bahasa Inggris "best friend" yang memiliki makna teman baik.

\section{b. Campur Kode ke Dalam (inner code mixing)}

Dialog berikut menunjukkan adanya campur kode ke dalam yang terjadi antara S1 dengan P1. Penggalan dialognya sebagai berikut.

$\begin{array}{ll}\text { Tape } 1 & \text { : Jumat, } 20 \text { Juli } 2012 \\ \text { Dialog } 1 & \text { : Kunjungan Rikka Fujii ke } \\ \text { Beberapa Negara }\end{array}$ Setting: Teras

S $1 \quad$ I $\rightarrow$ B : Enggak...saya pinter kamu baru belog.

P $1 \quad I \rightarrow$ B : Aits...tahu belog juga Rikka - san nok. Oo... ya Meto san ke mana?

Dialog di atas termasuk jenis campur kode ke dalam (inner code mixing), karena pada dialog diatas subjek mencampurkan dua bahasa yaitu bahasa Indonesia dan bahasa Bali. Bahasa Indonesia tersebut berupa dialog "Enggak...saya pinter kamu baru" dan tambahan kata dalam bahasa Bali "belog". Kata "belog" merupakan salah satu kata yang diketahui oleh subjek yang dalam bahasa Indonesia berarti bodoh. Kata-kata tersebut ditujukan subjek 1 kepada $P 1$ (partisipan 1) selaku temannya dalam situasi informal sebagai bahan guyonan dalam kegiatan berkomunikasi.

\section{c. Campur Kode Campuran (hybrid code mixing)}

Dialog berikut menunjukkan adanya campur kode campuran dalam kegiatan berkomunikasi antara S1 dengan P1. Penggalan dialognya tersaji di bawah ini. 
Tape 1

Dialog 1

: Jumat, 20 Juli 2012

:Kunjungan Rikka Fujii ke

Beberapa Negara

Setting :

Teras

S $1 \quad$ I $\rightarrow$ J $\rightarrow$ B : Udah kayak gitu lidahnya. Ano...susah dana bilang murih yang penting saya tau artinya.

Dialog di atas merupakan ujaran yang masuk dalam jenis campur kode campuran (hybrid code mixing), pada dialog ini terjadi tiga jenis percampuran bahasa yaitu bahasa Jepang, bahasa Indonesia, dan bahasa Bali. Bahasa Jepang ditunjukkan dengan kata "ano" dan "dana", bahasa Indonesia muncul pada kata "susah bilang" dan "yang penting saya tahu artinya" serta terakhir kata "mulih" yang diucapkan "murih" oleh subjek 1 merupakan bahasa Bali. Pada dialog ini subjek 1 merasa kesusahan dalam mengucapkan kata "mulih" karena lidah orang Jepang tidak terbiasa mengucapkan konsonan "L". Serta kemunculan kata-kata "ano" dan "dana" disebabkan karena kebiasaan berbicara bahasa Jepang oleh subjek 1 masih terbawa saat ia berbicara dalam bahasa Indonesia ataupun bahasa lainnya.

Jadi telah terjawab rumusan masalah pertama dalam penelitian ini bahwa pasangan perkawinan beda bangsa di daerah pariwisata Sanur menggunakan seluruh bentuk campur kode yang ada dalam kegiatan berkomunikasinya baik itu campur kode ke luar luar (outer code mixing), campur kode ke dalam (inner code mixing), serta campur kode campuran (hybrid code mixing) .

\section{Campur Kode yang Dominan Terjadi}

Setelah diketahui bahwa seluruh jenis campur kode digunakan dalam kegiatan komunikasi pada subjek penelitian, sesuai rumusan masalah penelitian No.2 peneliti ingin mengetahui jenis campur kode yang paling dominan digunakan dalam komunikasi lisan pasangan perkawinan beda bangsa di daerah pariwisata Sanur.
Adapun hasil yang peneliti peroleh adalah terjadi 59 dialog campur kode dalam percakapan pasangan dari perkawinan antarbangasa (warga Jepang-Indonesia) di daerah pariwisata Sanur.

Pembagiannya adalah dialog campur kode ke luar (outer code mixing) terjadi sebanyak 50 dialog dengan persentase sebesar $84,75 \%$, selanjutnya dialog campur kode ke dalam (inner code mixing) terjadi sebanyak 6 dialog dengan persentase $10,17 \%$, dan yang terakhir adalah dialog campur kode campuran (hybrid code mixing) yang hanya terjadi 3 kali dialog dengan persentase $5,08 \%$.

Sehingga sesuai dengan apa yang dipaparkan pada analisis data yang menyatakan bahwa jenis campur kode yang memperoleh persentase tertinggi adalah campur kode yang paling dominan terjadi dalam komunikasi lisan pasangan perkawinan beda bangsa (warga JepangIndonesia), dan sudah jelas bahwa jenis campur kode yang paling dominan terjadi adalah campur kode ke luar (outer code mixing) sebanyak 50 dialog dengan persentase $84,75 \%$.

\section{Alasan Subjek Penelitian Melakukan Campur Kode}

Selanjutnya rumusan masalah ke-3 dalam penelitian ini juga telah ditemukan jawabannya lewat analisis data yang diperoleh dari hasil wawancara yaitu pertimbangan pasangan perkawinan beda bangsa ini melakukan campur kode adalah faktor kebiasaan, kesantaian, dan kurangnya ungkapan pada bahasa lainnya.

\section{SIMPULAN}

Berdasarkan hasil dan pembahasan di atas dapat disimpulkan jenis campur kode yang digunakan oleh pasangan perkawinan beda bangsa (warga Jepang-Indonesia) adalah 3 jenis campur kode yaitu campur kode ke luar (outer code mixing), campur kode ke dalam (inner code mixing), dan campur kode campuran (hybrid code mixing). Adapun kemunculan dialog-dialog 
setiap jenis campur kode yaitu campur kode ke luar (outer code mixing) sebanyak 50 dialog $(84,75 \%)$, campur kode ke dalam (inner code mixing) sebanyak 6 dialog $(10,17 \%)$, dan campur kode campuran (hybrid code mixing) sebanyak 3 dialog $(5,08 \%)$.

Jenis campur kode yang paling banyak digunakan adalah campur kode ke luar (outer code mixing) sebanyak 50 dialog dengan persentase $84,75 \%$.

Alasan/pertimbangan keluarga dari perkawinan antarbangsa melakukan campur kode yaitu, (1) Faktor Kebiasaan, (2) Faktor Kesantaian, dan (3) Faktor Kurangnya Ungkapan

\section{DAFTAR PUSTAKA}

Anonim.2011. Bilingualisme. http:// wikipedia.com/bilingulisme (diakses 2 Februari 2012) 2011.

Definisi

Komunikasi.http://wikipedia.com/komu nikasi (diakses 2 Februari 2012)

------. 2011. Pemerolehan Bahasa. http://wikipedia.com/pemerolehanbahasa (diakses 2 Februari 2012)

Adnyani,Ni Luh Putu Sri.2010. Penggunaan Campur Kode oleh Keluarga dari Perkawinan Antarbangsa di Daerah Pariwisata Lovina.Parsi Vol.6 (hlm. 35-39)

Antara,Gusti Putu dan Ni Nyoman Garminah. 2004. Campur Kode dalam Bahasa Bali pada Etnik Jawa di Desa Tegallinggah Buleleng. Singajara: Artikel.IKIP Negeri Singaraja.

Arikunto, Suharsimi. 2002. Prosedur Penelitian Suatu Pendekatan Praktik. Jakarta: PT Rineka Cipta.

Azwarmana,I Gede Bayu. 2008. The Identification of Code Mixing Used by Local Guides at Gitgit During Their Break Time.Tugas Akhir (tidak diterbitkan).Undiksha

Barisanta,I Wayan. 2007.Campur Kode Bahasa Bali ke dalam Bahasa Bali yang Dilakukan Guru dalam PBM di Kelas IV SD Negeri 3 Pejeng
Kawan.Skripsi (tidak diterbitkan). Singaraja: Undiksha.

Chaer, Abdul dan Leoni Agustina.2004. Sosiolinguistik:Perken alan Awal: Jakarta. PT.Rineka Cipta

Departemen Pendidikan dan Kebudayaan. 2005. Kamus Besar Bahasa Indonesia.Jakarta: BalaiPustaka.

Effendy,Onong Uchjana. 2005.IImu Komunikasi Teori dan Praktek.Bandung: PT. Remaja Rosdakarya.

Jendra,I Wayan.1991. Dasar-Dasar Sosiolinguistik.Denpasar: Ikayana.

Kamaruddin.1989. Kedwibahasaan dan Pendidikan Dwibahasa (Pengantar). Jakarta: Departemen Pendidikan dan Kebudayaan.

Keraf,Gorys.1993.Terampil Berbahasa Indonesia 1.Jakarta: Balai Pustaka.

Moleong,Lexy J.2004.Metodelogi Penelitian Kualitatif.Bandung: PT. Remaja Rosdakarya.

Nababan, PWJ.1992.Sosiolinguistik Suatu Pengantar.Jakarta: Gramedia Pustaka Utama

Sugiyono.2006.Metode Penelitian Pendidikan (Pendekatan Kuantitatif, Kualitatif, dan R\&B). Bandung: Alfabeta

Suhardi, Basuki. 2009. Pedoman Penelitian Sosiolinguistik. Jakarta: Pusat Bahasa Departemen Pendidikan Nasional.

Suwito.1983.Pengantar Awal Sosiolinguistik Teori dan Problema. Surakarta: Universitas Sebelas Maret.

Wendra, I Wayan. 2009. Penulisan Karya IImiah. Singaraja: Undiksha. 